\title{
Pengaruh Pemberian Antibodi Poliklonal PMSG (Pregnant Mare Serum Gonadotropin) (Abpo PMSG) yang Berasal dari Kelinci (Oryctolagus cuniculus) Jantan terhadap Jumlah Fetus Mencit (Mus musculus)
}

\author{
Indra Rahmawati ${ }^{{ }^{*}}$ \\ Departemen Histologi Veteriner Fakultas Kedokteran Hewan \\ Universitas Wijaya Kusuma Surabaya ${ }^{1}$ \\ *e-mail: Indra_rachma07@yahoo.com
}

\begin{abstract}
Abstrak
Tujuan dari penelitian ini adalah untuk mengevaluasi pengaruh potensi produk PMSG (Pregnant Mare Serum Gonadotropin) terhadap jumlah fetus mencit. Metoda yang digunakan untuk penelitian ini adalah dengan menyuntikkan 0,1 ml PMSG (Pregnant Mare Serum Gonadotropin) pada tikus superovulasi dengan PMSG dan hCG. Ada enam perlakuan dalam penelitian ini. Kelompok kontrol adalah kelompok tikus yang hanya diovaskulasi. P1 diberi PMSG dan PMSG PMSG. P2 adalah kelompok tikus yang diberi Abpo diberikan 1 jam setelah PMSG, P3 diberi Abpo PMSG saat mereka mengalami masalah. P4 diberi Abpo PMSG 1 jam sebelum hCG, dan P5 diberi Abpo PMSG 1 jam setelah hCG. Hasil penelitian menunjukkan bahwa jumlah janin terbanyak berasal dari P3. Jumlah janin paling sedikit berasal dari kelompok kontrol. Angka janin P1, P2, P4 dan P5 menunjukkan tidak ada perbedaan yang signifikan dengan kelompok $\mathrm{P} 3(\mathrm{P}>0,05)$.
\end{abstract}

Kata Kunci: PMSG, Abpo PMSG, jumlah Fetus

\section{Potencial Test of Local Product PMSG (Pregnant Mare Serum Gonadotropin) Polyclonal Antibody (Abpo PMSG) Originated from Male Rabbit (Orictolagus cuniculus) on Mice (Mus musculus) Foetus Number}

\begin{abstract}
The purpose of this study was to evaluate the potencial influence local product Abpo PMSG treatment on mice foetus number. Methode used for this research was by injecting 0,1 $\mathrm{ml}$ Abpo PMSG on superovulated mice with PMSG and hCG. There were six treatments in this research. Control group was group of mice that only superovulated. P1 was given PMSG and Abpo PMSG together. $P 2$ was group of mice that wich Abpo given 1 hour after PMSG, P3 given Abpo PMSG when they were estrous. P4 given Abpo PMSG 1 hour before $h C G$, and P5 given Abpo PMSG 1 hour after hCG. The result showed that the most foetus number resulted from $P 3$. The least foetus number was from control group. Foetus number of P1, P2, P4 and P5 was showed no significant difference with $P 3$ group $(P>0.05)$.
\end{abstract}

Keywords: PMSG, Abpo PMSG, foetus number 
Pengaruh Pemberian Antibodi Poliklonal PMSG (Pregnant Mare Serum Gonadotropin)... Indra Rahmawati

\section{PENDAHULUAN}

Program Swasembada Daging Sapi dan Kerbau (PSDSK) tahun 2014 merupakan salah satu dari 21 program utama Kementerian Pertanian yang terkait dengan upaya mewujudkan ketahanan pangan hewani asal ternak berbasis sumber daya daerah. Program ini juga merupakan peluang untuk dijadikan pendorong dalam mengembalikan Indonesia sebagai negara pengekspor sapi seperti pada masa lalu. Tantangan tersebut tidak mudah karena saat ini impor daging dan sapi sangat besar, sekitar 30 persen dari kebutuhan daging nasional. Bahkan ada kecenderungan untuk impor terus meningkat (Direktorat Jenderal Peternakan dan Kesehatan Hewan, 2012).

Kemampuan produktivitas sapi potong dalam negeri belum memberikan hasil yang baik dalam memenuhi kebutuhan daging yang setiap tahun meningkat. Hal tersebut dapat diperbaiki dengan program pemerintah seperti adanya rencana target sasaran peningkatan populasi dan produksi daging sapi, untuk produksi daging tahun 20122013 diharapkan terjadi peningkatan. Impor daging sapi tahun 2012 sebesar $50,83 \%$ yang setara dengan 282.596 ekor, dan tahun 2013 sebesar 41,64 \% yang setara dengan $213,92 \%$. Target jumlah populasi sapi potong tahun 2012 sebesar
15.995.946 ekor dan tahun 2013 sebesar 16.816.218 ekor (Direktorat Jenderal Peternakan dan Kesehatan Hewan, 2012).

Beberapa teknologi yang digunakan untuk meningkatkan efisiensi reproduksi ternak adalah induksi birahi, penanganan kasus infertilitas atau gangguan reproduksi, inseminasi buatan, superovulasi dan transfer embrio. Pengelolaan sapi yang baik diharapkan mencapai hasil produksi dengan jarak beranak (calving interval) 12 bulan, sehingga pada akhirnya diharapkan dapat memenuhi kebutuhan daging sapi sebagai sumber protein hewani masyarakat Indonesia (Hermadi, et al, 2012). Tinggi rendahnya efisiensi reproduksi pada kelompok ternak tergantung pada pengelolaan reproduksi ternak baik secara individual maupun kelompok. Produktivitas ternak ditentukan oleh reproduktivitasnya. Oleh karena itu, perlu dibuat suatu program kesehatan reproduksi pada ternak yang efektif agar dapat menghasilkan efisiensi reproduksi yang lebih baik (Hariadi et al, 2011).

Salah satu upaya untuk meningkatkan populasi dan produksi sapi potong dalam negeri adalah meningkatkan efisiensi reproduksi induk melalui peningkatan jumlah pedet setiap kelahiran atau kelahiran kembar (twinning). Teknik reproduksi yang dapat digunakan untuk menghasilkan kelahiran kembar adalah 
1978-2071 (Print); ISSN 2580-5967 (Online) Jurnal IImiah Kedokteran Wijaya Kusuma 7(1) : 51-61, Maret 2018

superovulasi. Superovulasi merupakan cara untuk meningkatkan jumlah oosit yang diproduksi oleh ovarium melalui peningkatan jumlah kematangannya menjadi ovum, sehingga terjadi ovulasi dan akan diikuti peningkatan jumlah korpus luteum (Ratnawati et al, 2011).

Pemanfaatan Pregnant Mare Serum Gonadotrophin (PMSG) sebagai salah satu preparat hormon untuk superovulasi telah banyak digunakan di lapangan. Secara endokrinologi PMSG berasal dari serum kuda yang bunting. Sediaan PMSG yang banyak digunakan selama ini adalah produksi luar negeri (PMSG paten). Harga PMSG paten relatif mahal serta ketersediaannya di lapangan yang terbatas karena membutuhkan waktu yang cukup lama untuk mendapatkan hormon tersebut, sedangkan PMSG paten tersebut dibutuhkan setiap saat di lapangan. Hormon PMSG lokal merupakan salah satu alternatif pilihan dengan harga yang lebih terjangkau (Ratnawati et al, 2011). Pemberian PMSG sebagai preparat hormon untuk superovulasi pada sapi, memberikan hasil yang rendah dan bervariasi dalam persentase ovulasi (ovulation rate) dan hasil panennya berupa embrio layak transfer. Hasil panen embrio yang rendah diakibatkan oleh rangsangan 1anjutan PMSG yang memiliki waktu paruh (half life) panjang yakni mencapai 123 jam (Dielman et al, 1993). Residu PMSG yang masih beredar dalam sistem sirkulasi darah dan masih memiliki potensi biologis akan terus merangsang aktivitas ovarium. Ovarium yang terus terangsang akan menghasilkan folikel-folikel yang gagal berovulasi (persisten). Dampak lanjutan dan masih beredarnya PMSG dalam sirkulasi darah adalah gangguan keseimbangan hormonal, ovulasi, pembuahan (fertilisasi) dan pengangkutan embrio di saluran telur (Supriatna et al, 1998).

Ketersediaan anti-PMSG paten sama sulitnya dengan memperoleh PMSG paten, karena harus impor dengan biaya yang cukup mahal dan waktu tunggu yang lama. Penelitian ini dilakukan dengan tujuan untuk mengetahui biopotensi antibodi poliklonal PMSG lokal (Abpo PMSG lokal) yang berasal dari serum kelinci (Oryctolagus cuniculus) jantan terhadap perolehan jumlah fetus mencit (Mus musculus) yang disuperovulasi menggunakan kombinasi PMSG dan hCG.

\section{BAHAN DAN METODE}

Produksi Antibodi poliklonal PMSG (Abpo PMSG) dari PMSG (Gonaplas) pada Kelinci (Oryctolagus cuniculus) Jantan

Sebanyak 2 ekor kelinci (Oryctolagus cuniculus) jantan strain lokal diimunisasi dengan PMSG produk lokal. Kelinci 
Pengaruh Pemberian Antibodi Poliklonal PMSG (Pregnant Mare Serum Gonadotropin)... Indra Rahmawati

diimunisasi secara subkutan dengan suspensi $0,2 \mathrm{ml}$ PMSG dalam $0,2 \mathrm{ml}$ Complete Freund's Adjuvant (CFA) perbandingan 1:1. Booster dilakukan satu kali dengan 0,2 $\mathrm{ml}$ PMSG dalam 0,2 ml pelarut Incomplete Freund's Adjuvant (IFA) perbandingan $1: 1$, dengan interval 1 minggu. Booster pertama dilakukan 3 minggu setelah imunisasi pertama. Pengambilan darah untuk koleksi serum dilakukan dari vena auricularis sebanyak 5 6 cc dan dilakukan sebanyak 3 kali, yaitu sehari sebelum imunisasi pertama, setelah imunisasi pertama (sebelum booster pertama), setelah booster pertama. Darah yang didapat dibiarkan mengendap dan diambil serumnya, selanjutnya serum yang diperoleh dari kelinci tersebut dianalisis titer antibodi dengan indirect ELISA, selanjutnya Abpo PMSG tersebut digunakan untuk uji potensi terhadap kebuntingan dan jumlah fetus mencit (Mus musculus).

\section{Pelaksanaan Uji Biopotensi Abpo PMSG terhadap Perolehan Jumlah Fetus Mencit (Mus musculus)}

Perlakuan yang digunakan adalah sebagai berikut:

K : Mencit betina disuntik dengan PMSG 5 IUsecara intramuskular pada fase diestrus, dua hari kemudian mencit disuntik dengan hCG 5 IU secara intramuskular dan dikawinkan dengan mencit jantan tanpa disuntik Abpo PMSG.

P1 : Mencit betina disuntik dengan PMSG 5 IU bersamaan dengan $0,1 \mathrm{ml}$ dari pengenceran 20 kali Abpo PMSG secara intramuskular pada fase diestrus, dua hari kemudian mencit disuntik dengan hCG 5 IU secara intramuskular dan dikawinkan dengan mencit jantan.

P2 : Mencit betina disuntik dengan PMSG 5 IU secara intramuskular pada fase diestrus, satu jam setelah itu disuntik dengan $0,1 \mathrm{ml}$ dari pengenceran 20 kali Abpo PMSG secara intramuskular, dua hari kemudian mencit disuntik dengan hCG 5 IU secara intramuskular dan dikawinkan dengan mencit jantan.

P3 : Mencit betina disuntik dengan PMSG 5 IU secara intramuskular pada fase diestrus, dua hari kemudian mencit disuntik 0,1 ml dari pengenceran 20 kali Abpo PMSG bersamaan dengan hCG 5 IU secara intramuskular dan dikawinkan dengan mencit jantan.

P4 : Mencit betina disuntik dengan PMSG 5 IU secara intramuskular pada fase diestrus, dua hari kemudian disuntik dengan $0,1 \mathrm{ml}$ dari pengenceran 20 kali Abpo PMSG, 1 jam setelah itu disuntik hCG 5 IU secara intramuskular dan dikawinkan dengan mencit jantan.

P5 : Mencit betina disuntik dengan

PMSG secara intramuskular pada fase 
1978-2071 (Print); ISSN 2580-5967 (Online)

Jurnal IImiah Kedokteran Wijaya Kusuma 7(1) : 51-61, Maret 2018

diestrus, dua hari kemudian disuntik hCG 5

IU secara intramuskular dan dikawinkan dengan mencit jantan, setelah 1 jam disuntik $0,1 \mathrm{ml}$ dari pengenceran 20 kali Abpo PMSG secara intramuskular.

\section{HASIL}

\section{Produksi Antibodi Poliklonal PMSG (Abpo PMSG)}

Penelitian ini bertujuan untuk memproduksi antibodi poliklonal PMSG dari serum darah kelinci. Langkah awal dari tahap penelitian ini dilakukan melalui proses imunisasi aktif dengan Pregnant Mare Serum Gonadotropin (PMSG).

Sebanyak 2 Ekor kelinci diimunisasi dengan PMSG lokal (Gonaplas). Produksi Abpo PMSG ini dilakukan pada setiap kelinci dengan menyuntikkan 100 IU PMSG

yang dilarutkan dalam pelarut Complete Freund Adjuvant (CFA) dan di booster sebanyak 1 kali dengan 80 IU PMSG dalam pelarut Incomplete Freund Adjuvant (IFA). Kemudian dilakukan pengambilan darah sebanyak 3 kali pada vena auricularis di daerah telinga kelinci. Serum darah yang diperoleh bisa digunakan untuk superovulasi pada mencit.

\section{Kemampuan Abpo PMSG Lokal dalam Mempengaruhi Perolehan Jumlah Fetus Mencit (Mus musculus)}

Perhitungan jumlah perolehan
fetus mencit dilakukan dengan
pembedahan mencit bunting yang
dilakukan dengan pembedahan pada hari
ke-18 setelah perkawinan. Jumlah fetus
yang diperoleh dapat dilihat pada tabel
dibawah ini:

Tabel 1. Jumlah Rataan Fetus Mencit dengan penyuntikan Abpo PMSG local

\begin{tabular}{ccc}
\hline Perlakuan & N & Abpo PMSG local \\
\hline K (tanpa pemberian Abpo PMSG) & 5 & $3,20^{\mathrm{a}} \pm 1,92$ \\
P1 (Abpo PMSG bersamaan dengan & 5 & $3,40^{\mathrm{a}} \pm 2,80$ \\
PMSG) & & \\
P2 (Abpo PMSG 1 jam setelah PMSG) & 5 & $4,60^{\mathrm{ab}} \pm 1,14$ \\
P3 (Abpo PMSG saat estrus bersama & 5 & $7,00^{\mathrm{b}} \pm 1,00$ \\
hCG) & & \\
P4 (Abpo PMSG 1 jam sebelum hCG) & 5 & $5,60^{\mathrm{ab}} \pm 0,54$ \\
P5 (Abpo PMSG 1 jam setelah hCG) & 5 & $3,60^{\mathrm{a}} \pm 2,88$ \\
\hline
\end{tabular}

Tabel 1 merupakan Jumlah rataan fetus mencit kelompok kontrol dan perlakuan dengan penyuntikan Abpo PMSG lokal yang diperoleh setelah mencit dibedah. Angka dengan superskrip sama pada kolom yang sama menunjukkan tidak ada perbedaan yang nyata ( $p>0,05)$, superskrip yang berbeda dalam satu kolom menunjukkan adanya perbedaan yang nyata $(p<0,05)$.

Berdasarkan Tabel 1. diatas dapat diketahui bahwa pengaruh pemberian
Abpo PMSG lokal terhadap jumlah fetus mencit yang dibedah pada hari ke-18, 
Pengaruh Pemberian Antibodi Poliklonal PMSG (Pregnant Mare Serum Gonadotropin)... Indra Rahmawati

dengan uji Anova menunjukan hasil adanya perbedaan yang nyata $(p<0,05)$ pada setiap kelompok kontrol dan perlakuan, sehingga dapat dilanjutkan dengan uji Duncan yang menunjukkan hasil tertinggi pada kelompok P3 yang tidak berbeda nyata dengan kelompok P2 dan P4, akan tetapi berbeda nyata dengan kelompok kontrol, P1 dan P5. Sedangkan hasil terendah pada kelompok kontrol yang berbeda nyata dengan kelompok $\mathrm{P} 3$, akan tetapi tidak berbeda nyata dengan kelompok P1, P2, P4 dan P5.

Jumlah anak mencit yang dihasilkan dan gambarannya berdasarkan perbedaan waktu pemberian antibodi poliklonal PMSG pada kelompok kontrol dan kelompok perlakuan adalah sebagai berikut:

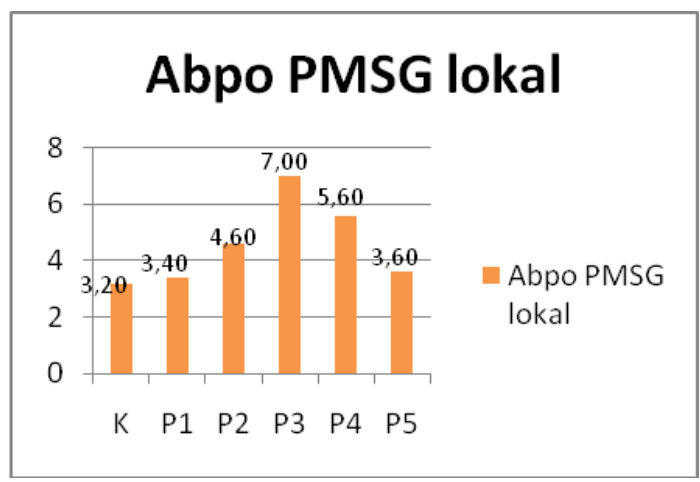

Gambar 1. Grafik Batang Perolehan Jumlah Fetus Mencit pada Kelompok Kontrol dan Perlakuan dengan Penyuntikan Antibodi Poliklonal PMSG (Abpo) Lokal

\section{PEMBAHASAN}

\section{Produksi Antibodi Poliklonal Anti- PMSG (Abpo PMSG)}

Pregnant Mare Serum Gonadotropin (PMSG) dianggap sebagai benda asing yang dimasukkan ke dalam tubuh kelinci dan nantinya akan dihasilkan antibodi yang disebut antibodi poliklonal PMSG (Abpo PMSG). Produksi antibodi dengan memasukkan antigen secara berulangulang disebut sebagai produksi serum hiperimun atau antibodi poliklonal. Imunisasi hormon protein dilakukan untuk mendapatkan anti protein dengan satu kali penyuntikkan dalam Complete Freund Adjuvant (CFA) dan diulang dengan penyuntikkan dalam Incomplete Freund Adjuvant (IFA) sebagai booster (Leenaar et al, 2005).

\section{Kemampuan Abpo PMSG terhadap Jumlah Fetus Mencit (Mus musculus)}

Penelitian ini bertujuan untuk mengetahui kemampuan Abpo PMSG dalam mempengaruhi jumlah fetus yang dihasilkan. Jumlah fetus yang diperoleh pada penelitian ini menunjukan hasil adanya pebedaan yang nyata dalam setiap perlakuan yang diberikan Tabel 1 dan diagram batang pada Gambar 1. Jumlah fetus terbanyak dihasilkan dari pemberian Abpo PMSG lokal pada kelompok P3 yaitu sebesar $7 \pm 1,0$ dan paling sedikit adalah kelompok kontrol yaitu $3,2 \pm 1,924$. Sedangkan untuk kelompok perlakuan P1, P2, P4 dan P5 didapatkan jumlah fetus 
1978-2071 (Print); ISSN 2580-5967 (Online) Jurnal IImiah Kedokteran Wijaya Kusuma 7(1) : 51-61, Maret 2018

sebesar $3,4 \pm 2,881 ; 4,6 \pm 1,140 ; 5,6 \pm$ 0,$548 ;$ dan $3,6 \pm 2,881$.

Berdasarkan uji statistik seperti pada Tabel 1 dapat diketahui bahwa pada hasil anak yang diperoleh setelah pemberian Abpo PMSG lokal, terdapat perbedan yang nyata $(p<0,05)$ dalam setiap masingmasing kelompok perlakuan terhadap jumlah anak mencit, yaitu dimana kelompok P3 berbeda nyata dengan kelompok kontrol, P1 dan P5. Hal ini berarti kelompok P3 lebih berpengaruh terhadap perolehan jumlah anak mencit dibandingkan dengan kelompok kontrol, P1 dan P5, akan tetapi kelompok P3 tidak berbeda nyata dengan kelompok P2 dan P4, yang berarti kelompok P2 dan P4 juga berpengaruh terhadap perolehan jumlah anak mencit.

Data statistik yang diperoleh menunjukkan hasil jumlah fetus terendah yaitu pada kelompok kontrol yang tidak berbeda nyata dengan kelompok P1, P2 dan P5 yang berarti Abpo PMSG dapat menetralisir kerja PMSG, dimana Abpo PMSG dapat diberikan pada saat bersamaan dengan PMSG, 1 jam setelah PMSG serta 1 jam setelah pemberian hCG.

Kelompok kontrol memiliki jumlah fetus yang rendah dikarenakan masih adanya pengaruh kerja yang panjang (long acting) dari PMSG sehingga menyebabkan suasana estrogenik pada uterus. Sama

halnya dengan pada perlakuan P1 dan P2 yaitu pemberian Abpo PMSG dilakukan bersamaan dengan PMSG dan 1 jam setelah PMSG maka akan menghasilkan jumlah anak yang sedikit karena Antibodi tersebut akan menetralisir kerja PMSG.

Pregnant Mare Serum Gonadotropin (PMSG) merupakan hormon eksogen yang mampu menggertak terjadinya superovulasi. Superovulasi adalah proses biologis pertumbuhan, pematangan dan pelepasan sel telur dari folikel ovarium yang melebihi dari normal. Mencit yang disuntik dengan kombinasi PMSG dan hCG dengan dosis yang sama yaitu 5 IU dan dikawinkan dengan pejantan akan mengalami proses superovulasi dengan menghasilkan embrio yang lebih banyak dari normal, dimana nantinya juga akan berpengaruh terhadap jumlah anak yang dihasilkan.

PMSG mempunyai aktivitas mirip FSH dan LH, meskipun efek FSH terlihat lebih dominan daripada LH (8). Secara alami PMSG akan merangsang pembentukan folikel pada ovarium, seperti kerja FSH. Beberapa folikel yang diovulasikan akan mengalami luteinisasi karena efek LH yang dimiliki oleh PMSG.

PMSG berperan dalam
folikulogenesis yakni pada folikel
primordial, PMSG akan meningkatkan
jumlah folikel pada stadium pertumbuhan.


Pengaruh Pemberian Antibodi Poliklonal PMSG (Pregnant Mare Serum Gonadotropin)... Indra Rahmawati

Folikel primordial dikenal sebagai folikel primer. Pembentukan folikel primer terjadi setelah terbentuk perkembangan oogonium menjadi oosit. Pertumbuhan oosit ditandai dengan bertambahnya kuning telur pada sitoplasma, Folikel primer mulai berkembang secara terusmenerus membentuk folikel sekunder setelah proses perkembangan oogonium menjadi oosit berakhir (Hafez, 20008).

Folikel sekunder berkembang menjadi folikel tersier yang ditandai oleh adanya perkembangan sel-sel granulosa sehingga folikel tampak lebih besar. Folikel de Graaf merupakan perkembangan bentuk terakhir dan terbesar dari folikel ovariunm. Terjadi proses pematangan oosit dibawah pengaruh LH sebelum ovulasi. Pecahnya folikel de Graaf dan keluarnya ovum dari dalam folikel disebut sebagai ovulasi.Sitoplasma oosit yang diovulasikan dikelilingi oleh membran vitelin, zona pelusida, dan kumulus ooporus (Partodihardjo, 1992).

Antibodi terhadap PMSG yang terbentuk akan mengadakan perlawanan atua menetralisir tergadap biopotensi PMSG dan reaksi superovulasi akan menghilang. Pemberian anti PMSG dengan dosis yang sama degan PMSG pada mencit akan menyebabkan penurunan kadar PMSG darah secara cepat dan kadar PMSG akan hilang dalam waktu 17 jam (Katagiri, 1991).

Penelitian anti PMSG yang disuntikan pada sapi 72 jam setelah injeksi PMSG dapat menghambat terjadinya superovulasi (Boryczko, 1994). Sapi yang disuntik anti-PMSG, kadar PMSG menurun tajam dan menghilang dalam waktu 2 jam setelah penyuntikan anti PMSG dan hal ini menunjukan bahwa PMSG dinetralkan oleh anti PMSG pada waktu akhir maturasi folikel (Dielman, 1993).

Hasil penelitian ini menunjukan bahwa perolehan jumlah fetus pada P3 yaitu pemberian Abpo saat estrus dan bersamaan dengan hCG serta pada perlakuan P4 yaitu pemberian Abpo PMSG 1 jam sebelum hCG memberikan hasil yang tinggi dibandingkan dengan perlakuan yang lainnya. Jumlah fetus yang meningkat disebabkan karena pemberian anti PMSG yang tepat. Keberhasilan perolehan jumlah fetus tergantung pada embrio yang ditentukan dari angka ovulasi. Pemakaian PMSG untuk tujuan superovulasi dapat menghasilkan sel telur yang belum masak dan abnormalitas embrio yang menjurus ke arah kematian embrio dini (Keller and Tepker, 1990). Pemberian antibodi poliklonal PMSG bersamaan dengan hCG mampu meningkatkan perolehan jumlah fetus mencit yang disuperovulasi dengan PMSG. 
1978-2071 (Print); ISSN 2580-5967 (Online)

Jurnal IImiah Kedokteran Wijaya Kusuma 7(1) : 51-61, Maret 2018

Human Chorionic Gonadotropin

(hCG) mempunyai efek fisiologis seperti LH sehingga dapat menyebabkan perkembangan dan pematangan folikel, merangsang sel granulosa dan sel theka dari folikel yang masak untuk memproduksi hormon estrogen sehingga dapat merangsang timbulnya birahi dan menggertak ovulasi (Partodihardjo, 1992).

Proses menuju fertilisasi sel sperma mengalami proses kapasitasi terlebih dahulu dalam tubuh hewan jantan dan hewan betina agar dapat bertemu dengan sel telur untuk melakukan fertilisasi. Spermatozoa yang telah sampai pada tempat fertilisasi akan berusaha memasuki sel telur dengan menembus sel kumulus, zona pelusida dan selaput vitelin. Sel-sel kumulus dapat ditembus dapat ditembus karena pergerakan sel spermatozoa dan dibantu oleh enzim hialuronidase. Zona pelusida dapat ditembus oleh spermatozoa oleh bantuan enzim zona lizin dan spermatozoa akan bersentuhan dengan selaput vitelin. Selaput vitelin selanjutnya akan mengadakan reaksi pengeblokan untuk mencegah masuknya spermatozoa lebih dari satu.

Zigot terbentuk dari hasil pertemuan spermatozoa dengan sel telur. Zigot yang terbentuk akan mengalami beberapa pembelahan sampai terdiri dari berpuluhpuluh sel kecil yang disebut blastomere.
Blastomere membelah membentuk bentukan seperti bola yang tidak berongga dan disebut sebagai morula. Morula akan membelah dan meyusun diri membentuk control cavity sehinga membentuk blastosyt.

Zigot mengalami pembelahan sel yang dimulai sejak zigot berada dalam tuba falopii. Pembelahan pertama pada stadium 2 sel terjadi 24 jam setelah ovulasi dan diikuti pembelahan-pembelahan selanjutnya sambil diikuti perpindahan dari tuba falopii ke uterus. Waktu yang dibutuhkan dalam pembentukan embrio mencit stadium 2 sel adalah satu hari, 2,5 hari untuk embrio stadium 8 sel, umur 3 hari sudah masuk dalam uterus dan blastosyt terbentuk 3,5 hari setelah fertilisasi (Partodihardjo, 1992).

Proses awal terbentuknya blastosyt sampai menuju uterus diawali dengan terjadinya relaksasi saluran uterus dicapai dalam waktu 80-108 jam setelah kopulasi. Pada hari 9-10 umur kebuntingan sudah mulai terbentuk garis primitif, walaupun bila dilihat dari permukaan selaput yang membungkus embrio belum tampak jelas. Selaput amnion lengkap sudah terbentuk disertai proliferasi daun kecambah. Terbentuknya selaput allantois, mulai berfungsinya hati serta alat-alat peredaran darah fetus terjadi pada kisaran waktu tersebut. Terbentuknya sepasang somit 
Pengaruh Pemberian Antibodi Poliklonal PMSG (Pregnant Mare Serum Gonadotropin)... Indra Rahmawati

pertama yaitu pada hari ke-10 akan segera diikuti oleh pasangan-pasangan berikutnya sehingga dalam waktu 24 jam telah terbentuk 10 pasang somit. Anggota badan bagian depan terbentuk ketika somit sudah mencapai 20 pasang yang diikuti pertumbuhan ekor. Memasuki umur kebuntingan hari ke 15 , sudah terbentuk 60 pasang somit dan mulai terlihat pergerakan dari fetus sampai pada saat dilahirkan pada umur kebuntinga 19-21 hari (Knobil, 1988).

Pemberian anti PMSG dapat menetralkan efek PMSG secara in vivo dan meningkatkan jumlah embrio layak transfer bila diberikan pada saat LH pra ovulasi. Netralisasi PMSG setelah puncak LH pra ovulasi akan menekan pengaruh PMSG pada akhir maturasi folikel dan meningkatkan angka ovulasi (Dielman, 1997).

\section{KESIMPULAN}

Pemberian Abpo PMSG
menunjukkan hasil yang signifikan
terhadap jumlah fetus mencit yang
dihasilkan pada program superovulasi
dengan menggunakan kombinasi PMSG
dan hCG.

\section{SARAN}

1. Pada program superovulasi dan transfer embriodengan menggunakan preparat
PMSG, perlu kiranya diikuti dengan pemberian antibodi poliklonal PMSG (Abpo PMSG) untuk mencegah adanya birahi yang berkepanjangan, perkembangan folikel yang berkelanjutan setelah ovulasi dan menjaga agar suasana uterus tidak estrogenik sehingga embrio yang didapatkan lebih baik kualitasnya dengan jumlah embrio lebih banyak.

2. Penggunaan Abpo PMSG lokal bisa digunakan sebagai alternatif di lapangan untuk menggantikan Abpo PMSG paten yang harganya mahal.

\section{DAFTAR PUSTAKA}

Boryczko Z, Bostedt H, Gajewski Z, Witkowski $M$, and Hoffmann B, 1994. Morphological and Hormonal Changes After Superovulation in Cows Treated with Neutral-PMSG. Arch. Vet. Pol. 34 (1-2): 117-126.

Dielman SJ, Bevers MM, Vos $\mathrm{P}$ and Deloos $F$, 1993. PMSG, Anti-PMSG in Catttle- A Simple and Efficient Superovulatory Treatment. Theriogenology. 39(1): 25-41.

Direktorat Jenderal Peternakan dan Kesehatan Hewan, 2012. Keterpaduan Program/ Kegiatan Pengembangan Sapi/ Kerbau di Tingkat Kab. / Kota. Musyawarah 
Rencana

Pembangunan

Pertanian. Jakarta.

Hafez ESE, 2000. Reproduction in Farm Animal. Lippincott Williams \& Wilkins. Philadelphia. 192-217.

Hariadi M, Hardjoputranto S, Wurlina $H$, Utomo B, Rimayanti, Triana IN, dan Rartnan H, 2011. Buku Ajar IImu Kemajiran pada Ternak. Airlangga University Press. Surabaya.

Hermadi HA, dan Mahaputra L, 2012. Produksi Equine Chorionic Gonadotropin (cCG) Frozen Dry dari Serum Kuda Bunting Lokal untuk Peningkatan Kebuntingan Sapi Madura. Laporan Penelitian Unggulan Perguruan Tinggi Tahun Anggaran 2012. Universitas Airlangga. Surabaya.

Katagiri S, Takahashi Y, Hishinuma M., Kanagawa H, Dochi $\mathrm{O}$, and Takakura H, 1991. PMSG Profiles in Superovulated and Anti-PMSG Antiserum Treated Mice and Heifers with Enzymeimmunoassay. Jpn J Vet Res. 39(1): 11-21.

Keller DS, and Tepker, 1990. Effect of Variability in Response to Superovulation on Donor Cow Selection Differentials in Nucleus
Breeding Schemes. J. Dairy Sci. 73 (2): 549-554.

Knobil E, Neill JD, Ewing LL, Greenwald GS, Markert CL, and Pfaff DW, 1988. The Physiology of Reproduction. Volume2. New York: Raven Press. Leenaar M, and Hendriksen CFM, 2005. Critical Steps in the Production of Polyclonal and Monoclonal Antibodies Evaluation and Recommendations. ILAR Journal. 46(3):269-279.

Partodihardjo S, 1992. IImu Reproduksi Hewan. Cetakan ke-3. Jakarta: Mutiara Sumber Widya.

Ratnawati D, Dikman DM, dan Efendy J, 2011. Pemanfaatan PMSG Lokal sebagai Alternatif Hormon Superovulasi. Seminar Nasional Teknologi Peternakan dan Veteriner. Hal: 32-37.

Supriatna I, Yusuf TL, Purwantara B, Moekti G, dan Hernomoadi LP, 1998. Kajian Pemberian Human Chorionic Gonadotropin (hCG) pada Sapi Perah yang Telah di Superovulasi dengan PMSGMonoclonal Antibodi (PMSGMoAb) Anti-PMSG. Media Veterniner. 5(2): 15-20. 